\title{
How should we treat vascular and fibrotic lung disease in scleroderma?
}

\author{
Jared N Kravitz and Charlie Strange*
}

\author{
Address: Division of Pulmonary and Critical Care Medicine, Medical University of South Carolina, 96 Jonathan Lucas St, Suite 812 CSB, \\ Charleston, SC 29425, USA \\ * Corresponding author: Charlie Strange (strangec@musc.edu) \\ FI000 Medicine Reports 2009, I:57 (doi:10.34I0/MI-57)
}

The electronic version of this article is the complete one and can be found at: http://FI000.com/Reports/Medicine/content/I/57

\begin{abstract}
Recent randomized trials suggest that evidence-based algorithms for systemic sclerosis can be developed to identify patients at risk for lung disease, follow lung disease progression, and modify disease with therapies of proven benefit. Recognition of disease subsets allows physicians to integrate physiology, overlapping disease manifestations, and predictable drug effects into a comprehensive disease management program.
\end{abstract}

\section{Introduction and context}

Pulmonary disease is the leading cause of morbidity and mortality from systemic sclerosis (SSc) [1]. The two most common pulmonary complications of SSc are interstitial lung disease (SSc-ILD) and pulmonary arterial hypertension (SSc-PAH). Management focuses on declaring all SSc patients at risk for these complications, prompting mandatory screening for lung disease.

SSc-ILD is present in up to $80 \%$ of patients when objectively assessed with computed tomography (CT) [2]. Defining who needs treatment remains controversial. Similarly, SSc-PAH may be clinically silent at early stages. Although the estimated prevalence of SSc-PAH is $27 \%$ [3], it tends to occur a decade or more following disease onset [4].

The risk of SSc-ILD appears highest in the diffuse cutaneous (dc-SSc) subset of disease, and the risk of SSc-PAH appears highest in the limited cutaneous (lc$\mathrm{SSc}$ ) subset. Gene expression studies reveal widespread differences in the basic biological features of these two subsets [5], with some experts considering them completely independent diseases. Recent studies, however, show blurring of the clinical boundaries between the subsets with regard to ILD risk [6].
dc-SSc, particularly if characterized by autoantibodies to DNA topoisomerase-1 (anti-Scl-70) [7], frequently leads to aggressive SSc-ILD. Since the greatest decline in forced vital capacity (FVC) occurs within the first 5 years [8], all patients should receive serial pulmonary function testing. Screening CT remains controversial as many will be abnormal in the absence of pulmonary symptoms or evidence of declining lung function.

lc-SSc, characterized by an anti-centromere autoantibody pattern on anti-nuclear antibody testing, often leads to more severe vascular disease. Raynaud syndrome with digital ulcerations frequently precedes SSc-PAH [4], the most common cause of death in this subset. Diffusion capacity of the lung for carbon monoxide $\left(D_{L} C O\right)$ reduction in isolation [9] and an increased predicted FVC percentage/predicted $\mathrm{D}_{\mathrm{L}} \mathrm{CO}$ percentage ratio [4] are risk factors. Right heart catheterization remains the gold standard to confirm a PAH diagnosis.

Treatment of SSc-ILD to date has been haphazard, with a variety of therapies applied and reported in case series and randomized trials $[10,11]$. In the majority of patients, the disease slowly progresses with an estimated mortality of $42 \%$ within 10 years [12]. Therefore, treatment trials to prove efficacy must be, by necessity, 
of long duration and/or involve large numbers of patients.

The previous 1 -year mortality of $50 \%$ reported in SScPAH [13], on the contrary, is not seen in the current treatment era [14] as treatment options have expanded. A broad consensus that long-term placebo-controlled trials in SSc-PAH are not ethical has emerged, despite the fact that none of the current drug trials has been subjected to the rigors necessary to prove a survival benefit of PAH drugs.

Another conundrum faced by physicians is the SSc patient with both pulmonary hypertension $(\mathrm{PH})$ and SSc-ILD [15]. PH results from vascular destruction by the fibrosis of ILD, pulmonary arteriolar remodeling and plexiform arteriopathy (SSc-PAH), or pulmonary venous hypertension due most commonly to a non-compliant left ventricle (LV) resulting in diastolic dysfunction. Pathologically, myocardial fibrosis without muscular hypertrophy has been noted in SSc autopsy series as a common finding [16].

\section{Recent advances Interstitial lung disease}

In clinical trials, the most robust endpoint for progressive lung function decline in SSc-ILD is FVC; however, the decline may not be linear. In a retrospective review [17], if a baseline predicted FVC of less than $80 \%$ occurred by 3 years compared with 5 years after disease onset, a further decline of at least $15 \%$ was more likely in the early-onset group.

Another study [18] defined disease extent on CT as mild ( $<10 \%$ involvement) or extensive ( $>30 \%$ involvement) and demonstrated that extensive disease was associated with further FVC and $\mathrm{D}_{\mathrm{L}} \mathrm{CO}$ decline, and a higher mortality. Combined, these two studies suggest that early ILD onset and more severe disease are more prone to further advance. Biologically, the concept that fibrosis begets more fibrosis implies that the patients likely to benefit from treatment are those with the most extensive disease.

The Scleroderma Lung Study (SLS) [19] and the Fibrosing Alveolitis in Scleroderma Trial (FAST) [20], using oral or intravenous cyclophosphamide (CYC), respectively, showed comparable results of a modest preservation of FVC in the CYC-treated subjects during the time of active treatment. In SLS, secondary outcomes also improved, including Short-Form 36 quality-of-life scores [21]. These studies suggest that SSc-ILD is treatable, but longer-term effective treatment options are needed. Our current treatment practice is an 18-month oral CYC course, with dose determined by toxicity monitoring, followed by a drug holiday. Whether mycophenolate mofetil will be able to replace or extend the CYC treatment effect remains to be determined in clinical trials.

\section{Pulmonary arterial hypertension}

SSc-PAH therapy appears to improve survival compared with historical controls [14]. Most clinical trial cohorts, however, include SSc patients as a subgroup of other $\mathrm{PAH}$ disease states. These studies conclude that the outcome for SSc-PAH is not as good as for idiopathic $\mathrm{PAH}$ [22], although the reason for this observation is unclear. Most experts speculate that the systemic nature of SSc adds vascular morbidity to other organ systems and affects outcome. Furthermore, many SSc patients enrolled in PAH trials are allowed to enter when a mild amount of ILD or LV dysfunction is present.

SSc patients with both clinically significant ILD and PH, however, are excluded from all current studies. Our treatment experience is similar to that of others [23]. This group has high baseline predicted mortality and yet can have a beneficial clinical response when thoughtfully treated for the individual disease components. We begin with a right and left heart catheterization to define the extent of $\mathrm{LV}$ disease before beginning therapy for PAH, SSc-ILD, and LV diastolic dysfunction if present. Since the 6-minute walk test is useful for defining improvement in all of these disease states, we use this test to define whether clinical improvement is occurring, provided that the distance walked is dyspnealimited [24].

\section{Implications for clinical practice}

Every SSc patient should be screened with serial spirometry. Abnormal spirometry should prompt a more comprehensive evaluation with $\mathrm{CT}$ and echocardiography. Dyspnea in the presence of normal spirometry should also be evaluated with CT and echocardiography, and if these prove normal, more intensive evaluation should be done. Treatment decisions for ILD include a thoughtful evaluation of disease extent and patient preferences, since delays in treatment until the predicted FVC is less than $70 \%$ or the CT extent is greater than $30 \%$ could be associated with disabling symptoms that may be incompletely reversed. Treatment decisions concerning PAH therapy are currently based on World Health Organization class and are similar to other PAH disease states as recommended by guidelines [25].

\section{Abbreviations}

CT, computed tomography; CYC, cyclophosphamide; dc-SSc, diffuse cutaneous systemic sclerosis; $\mathrm{D}_{\mathrm{L}} \mathrm{CO}$, 
diffusion capacity of the lung for carbon monoxide; FAST, Fibrosing Alveolitis in Scleroderma Trial; FVC, forced vital capacity; lc-SSc, limited cutaneous systemic sclerosis; LV, left ventricle; $\mathrm{PH}$, pulmonary hypertension; SLS, Scleroderma Lung Study; SSc, systemic sclerosis; SScILD, systemic sclerosis-related interstitial lung disease; SSc-PAH, systemic sclerosis-related pulmonary arterial hypertension.

\section{Competing interests}

JNK declares that he has no competing interests. CS has been a consultant for Actelion (Allschwil, Switzerland), Encysive (Houston, TX, USA), and Gilead (Foster City, CA, USA). He performs clinical trials with funding from the National Institutes of Health (Bethesda, MD, USA), Actelion, Pfizer Inc (New York, NY, USA), and FibroGen (San Francisco, CA, USA) and is on the speakers' bureau for Actelion and Gilead.

\section{References}

I. Steen VD, Medsger TA Jr: Changes in causes of death in systemic sclerosis, 1972-2002. Ann Rheum Dis 2007, 66:940-4.

FI000 Factor 3.0 Recommended Evaluated by Oliver Distler 07 Sep 2007

2. Ferri C, Valentini G, Cozzi F, Sebastiani M, Michelassi C, La Montagna G, Bullo A, Cazzato M, Tirri E, Storino F, Giuggioli D, Cuomo G, Rosada M, Bombardieri S, Todesco S, Tirri G; Systemic Sclerosis Study Group of the Italian Society of Rheumatology (SIRGSSSc): Systemic sclerosis: demographic, clinical, and serologic features and survival in 1,012 Italian patients. Medicine (Baltimore) 2002, 81: I39-53.

3. Wigley FM, Lima JA, Mayes M, McLain D, Chapin JL, Ward-Able C: The prevalence of undiagnosed pulmonary arterial hypertension in subjects with connective tissue disease at the secondary health care level of community-based rheumatologists (the UNCOVER study). Arthritis Rheum 2005, 52:21 25-32.

4. Steen V, Medsger TA Jr: Predictors of isolated pulmonary hypertension in patients with systemic sclerosis and limited cutaneous involvement. Arthritis Rheum 2003, 48:516-22.

5. Milano A, Pendergrass SA, Sargent JL, George LK, McCalmont TH, Connolly MK, Whitfield ML: Molecular subsets in the gene expression signatures of scleroderma skin. PLOS ONE 2008, 3: e2696.

6. Goldin JG, Lynch DA, Strollo DC, Suh RD, Schraufnagel DE, Clements PJ, Elashoff RM, Furst DE, Vasunilashorn S, McNittGray MF, Brown MS, Roth MD, Tashkin DP, Scleroderma Lung Study Research Group: High-resolution CT scan findings in patients with symptomatic scleroderma-related interstitial lung disease. Chest 2008, I34:358-67.

7. Steen VD: Autoantibodies in systemic sclerosis. Semin Arthritis Rheum 2005, 35:35-42.

8. Steen VD, Conte C, Owens GR, Medsger TA Jr: Severe restrictive lung disease in systemic sclerosis. Arthritis Rheum 1994, 37:1283-9.

9. MacGregor AJ, Canavan R, Knight C, Denton CP, Davar J, Coghlan J, Black CM: Pulmonary hypertension in systemic sclerosis: risk factors for progression and consequences for survival. Rheumatology (Oxford) 200I, 40:453-9.

10. Steen VD, Lanz JK Jr, Conte C, Owens GR, Medsger TA Jr: Therapy for severe interstitial lung disease in systemic sclerosis. A retrospective study. Arthritis Rheum 1994, 37:1290-6.

II. Silver RM, Warrick JH, Kinsella MB, Staudt LS, Baumann MH, Strange C: Cyclophosphamide and low-dose prednisone therapy in patients with systemic sclerosis (scleroderma) with interstitial lung disease. J Rheumatol 1993, 20:838-44.

12. White B: Interstitial lung disease in scleroderma. Rheum Dis Clin North Am 2003, 29:371-90.

13. Koh ET, Lee P, Gladman DD, Abu-Shakra M: Pulmonary hypertension in systemic sclerosis: an analysis of 17 patients. $\mathrm{Br} J$ Rheumatol 1996, 35:989-93.

14. Williams MH, Das C, Handler CE, Akram MR, Davar J, Denton CP, Smith CJ, Black CM, Coghlan JG: Systemic sclerosis associated pulmonary hypertension: improved survival in the current era. Heart 2006, 92:926-32.

15. Strange C, Bolster M, Mazur J, Taylor M, Goassage JR, Silver R: Hemodynamic effects of epoprostenol in patients with systemic sclerosis and pulmonary hypertension. Chest 2000, I 1 8: 1077-82.

16. D'Angelo WA, Fries JF, Masi AT, Shulman LE: Pathologic observations in systemic sclerosis (scleroderma). A study of fifty-eight autopsy cases and fifty-eight matched controls. Am J Med 1969, 46:428-40.

17. Plastiras SC, Karadimitrakis SP, Ziakas PD, Vlachoyiannopoulos PG, Moutsopoulos HM, Tzelepis GE: Scleroderma lung: initial forced vital capacity as predictor of pulmonary function decline. Arthritis Rheum 2006, 55:598-602.

18. Goh NS, Desai SR, Veeraraghavan S, Hansell DM, Copley SJ, Maher TM, Corte TJ, Sander CR, Ratoff J, Devaraj A, Bozovic G, Denton $\mathrm{CP}$, Black CM, du Bois RM, Wells AU: Interstitial lung disease in systemic sclerosis $\mathbf{A}$ simple staging system. Am J Respir Crit Care Med 2008, I 77: I248-54.

FI000 Factor 4.8 Must Read

Evaluated by Jay H Ryu 28 May 2008, Oliver Distler 09 Sep 2008

19. Tashkin DP, Elashoff R, Clements PJ, Goldin J, Roth MD, Furst DE, Arriola E, Silver R, Strange C, Bolster M, Seibold JR, Riley DJ, Hsu VM, Varga J, Schraufnagel DE, Theodore A, Simms R, Wise R, Wigley F, White B, Steen V, Read C, Mayes M, Parsley E, Mubarak K, Connolly K, Golden J, Olman M, Fessler B, Rothfield N, et al.; Scleroderma Lung Study Research Group: Cyclophosphamide versus placebo in scleroderma lung disease. $N$ Eng $J$ Med 2006, 354:2655-66.

Changes Clinical Practice

FI000 Factor 6.4 Must Read

Evaluated by Jay H Ryu I4 Sep 2006, Fernando Martinez 22 Sep 2006

20. Hoyles RK, Ellis RW, Wellsbury J, Lees B, Newlands P, Goh NS, Roberts C, Desai S, Herrick AL, McHugh NJ, Foley NM, Pearson SB, Emery P, Veale DJ, Denton CP, Wells AU, Black CM, du Bois RM: A multicenter, prospective, randomized, double-blind, placebocontrolled trial of corticosteroids and intravenous cyclophosphamide followed by oral azathioprine for the treatment of pulmonary fibrosis in scleroderma. Arthritis Rheum 2006, 54:3962-70.

FI000 Factor 3.0 Recommended

Evaluated by Fernando Martinez 30 Jan 2007

21. Khanna D, Yan X, Tashkin DP, Furst DE, Elashoff R, Roth MD, Silver R, Strange C, Bolster M, Seibold JR, Riley DJ, Hsu VM, Varga J, Schraufnagel DE, Theodore A, Simms R, Wise R, Wigley F, White B, Steen V, Read C, Mayes M, Parsley E, Mubarak K, Connolly MK, Golden J, Olman M, Fessler B, Rothfield N, Metersky M, et al.; Scleroderma Lung Study Group: Impact of oral cyclophosphamide on health-related quality of life in patients with active scleroderma lung disease. Results from the scleroderma lung study. Arthritis Rheum 2007, 56:1676-84.

FI000 Factor 3.0 Recommended

Evaluated by Martin Aringer II Jul 2007

22. McLaughlin VV, Presberg KW, Doyle RL, Abman SH, McCrory DC, Fortin T, Ahearn G: Prognosis of pulmonary arterial hypertension: ACCP evidence-based clinical practice guidelines. Chest 2004, I 26:78S-92S. 
23. Mathai SC, Hummers LK, Champion HC, Wigley FM, Zaiman A, Hassoun PM, Girgis RE: Survival in pulmonary hypertension associated with scleroderma spectrum of diseases. Impact of interstitial lung disease. Arthritis Rheum 2009, 60:569-77.

FI000 Factor 3.2 Recommended

Evaluated by Jay H Ryu 13 Feb 2009, Otylia Kowal-Bielecka 16 Mar 2009
24. Garin MC, Highland KB, Silver RM, Strange C: Limitations to the 6-minute walk test in interstitial lung disease and pulmonary hypertension in scleroderma. J Rheumatol 2009, 36:330-6.

25. Badesch DB, Abman SH, Simonneau G, Rubin LJ, McLaughlin VV: Medical therapy for pulmonary arterial hypertension: updated ACCP evidence-based clinical practice guidelines. Chest 2007, I31:1917-28. 